\title{
Industrial Property and Space Activities: Legal Protection
}

\author{
Tatiana Harbuz \\ Ph.D., Research Institute of Public Law (Kyiv, Ukraine) \\ E-mail: talexgarbuz@gmail.com
}

\begin{abstract}
Space activities and industrial property belonging to it play an increasingly important role in the creation of national treasures. It is for these reasons that the legal protection of industrial property objects has a number of issues that need to be clarified: increasing the level of administrative and legal protection of industrial property objects; improvement of national legislation; its compliance with international and European standards. The purpose of the article is to study the peculiarities of legal regulation and legal protection of industrial property objects. The exact establishment of the object of legal protection should be conditioned by the existing system of legal protection. In order to improve the legal protection of rights to geographic indications, the author proposed to amend the Art. 51-2 Code of Ukraine on Administrative Offenses, by including this object in accordance with the provisions of the article.

Keywords: industrial property; space activities; legal protection; intellectual property.
\end{abstract}

\section{Промислова власність та космічна діяльність: правова охорона}

\section{Гарбуз, Тетяна Олександрівна}

Кандидат юридичних наук, Науково-дослідний інститут публічного права

(Київ, Україна)

Космічна діяльність та об’єкти промислової власності щзо входять до неї відіграють все важливіме значення у створенні начіональних багатств. Саме з ичих причин правова охорона об 'єктів промислової власності має ичілу низку питань, щчо потребують свого роз 'яснення: підвищення рівня адміністративно-правової охорони об'єктів промислової власності, удосконалення національного законодавства, його відповідність міжнародним та європейським нормам. Метою статті є дослідження особливостей нормативно-правового регулювання та правової охорони об 'єктів промислової власності. Точне встановлення об'єкта правової охорони повинне бути зумовлене й існуючою системою охорони права на географічне зазначення походження товару законодавством України. 3 метою удосконалення правової охорони прав на географічне зазначення, автор запропанувала внести зміни до ст. 51-2 Кодексу Украӥни про адміністративні правопорушення шляхом включення цього об'єкта до норм статті.

Ключові слова: промислова власність; космічна діяльність; правова охорона; інтелектуальна власність.

(C) Harbuz, Tatiana, 2018 
Received: January 18, 2018; accepted: February 14, 2018

Advanced Space Law, Volume 1, 2018: 40-56..

https://doi.org/10.29202/as1/2018/1/6

\section{Ветуп}

Космічна діяльність та об'єкти промислової власності що входять до неї відіграють все важливіше значення у створенні національних багатств. Наприклад, на 8 листопада 2017 року тільки у структурах Національного управління аеронавтики та космічного простору (NASA) працювало 17,4 тис. державних службовців. Кожна структура NASA володіє інтелектуальною власністю та об'єктами промислової власності, що потребують правової охорони. Щоб зрозуміти масштаб правового захисту об'єктів NASA достатньо визначити головні напрями діяльності відповідно яких і формується структура NASA [NASA 2018, 2017]:

1. Дирекція з наукових місій (The Science Mission Directorate (SMD) розширює межі науки про Землю, геліофізику, планетарну науку і астрофізику. Використовуючи роботизовані обсерваторії, корабель-дослідник, наземні інструменти, SMD розширює знання про нашу сонячну систему, найвіддаленіші простори і часу.

2. Дирекція Місії з аеронавтики (The Aeronautics Research Mission Directorate (ARMD) трансформує авіацію відповідно досліджень, щоб значно зменшити вплив на навколишнє середовище від польоту, а також поліпшує ефективність літаків і безпеку польотів у все більш переповнених небесах. ARMD також генерує інноваційні авіаційні концепції, інструменти та технології для розвитку та вдосконалення авіаційної спільноти.

3. Дирекція Місії космічних технологій (The Space Technology Mission Directorate (STMD) досліджує і впроваджує технології, які мають високий потенціал для компенсації майбутніх ризиків космічних місій, зниження витрат і розвитку існуючих можливостей.

4. Дирекція місії з дослідження та операцій з людськими ресурсами (The Human Exploration and Operations Mission Directorate (HEOMD) досліджує умови життєдіяльності людини на орбіті Землі та за їі межами, розробляючи нові транспортні системи та виконуючи наукові дослідження для забезпечення стійкого та доступного людського життя за межами Землі. HEOMD також керує космічними комунікаційними та навігаційними послугами для Агентства та його міжнародних партнерів.

5. Управління підтримки місії (The Mission Support Directorate (MSD) забезпечує місії Агентства шляхом управління інституційними послугами та можливостями. MSD активно знижує інституційний ризик для поточних і майбутніх місій HACA, покращуючи процеси, стимулюючи ефективність і забезпечуючи узгодженість i однорідність у всіх інституційних стандартах і практиці.

6. Офіси адміністративного персоналу (The Administrator's Staff Offices) керує Агентством, надаючи вказівки та напрямки, які координують всю роботу НАCA. Ці офіси представляють Адміністратора з точки зору безпеки та забезпечення мі- 
сії, управління робочою силою та іiі різноманітністю, нагляд за придбанням та використанням інформаційних технологій, проведення фінансових операцій та операцій з закупівель, а також координацію міжнародних партнерств, законодавчих справ та діяльності STEM.

7. Офіс Генерального інспектора (The Office of Inspector General (ОІГ) сприяє економії, ефективності та інституалізації в Агентстві шляхом проведення незалежних та об’єктивних перевірок, розслідувань та оцінок програм та операцій Агентства. ОІГ гарантує якісне використання коштів платників податків та цілісність Агентства шляхом виявлення та запобігання шахрайства, відходів та зловживань.

Загалом річний бюджет NASA у 2017 році складає 19,5 млрд. доларів. Підкреслимо, що це масштаб окремої організації яка належить окремої державі. Саме з цих причин правова охорона об'єктів промислової власності має цілу низку питань, що потребують свого роз'яснення: підвищення рівня адміністративно-правової охорони об'єктів промислової власності, удосконалення національного законодавства, його відповідність міжнародним та європейським нормам.

У рамках поставленої мети слід звернути увагу, що удосконалення законодавства та розробка ефективних механізмів правової охорони суб'єктів права інтелектуальної власності та об'єкти промислової власності, що належать таким суб'єктам, є важливим фактором забезпечення зростання науково-технічного потенціалу України. Ця ефективність залежить від досконалості нормативно-правової бази, сформованої інфраструктури національної системи правової охорони інтелектуальної власності, ефективності підготовки та підвищення кваліфікації працівників.

Метою статті є дослідження особливостей нормативно-правового регулювання та правової охорони об'єктів промислової власності.

\section{Результати дослідження}

Проблему, що розглядається, досліджували вчені-адміністративісти М. Галянтич, О. Орлюк, О. Світличний, О. Тандир, О.Чомахашвілі та інші, а також представники інших галузевих наук. Проте особливості правової охорони об’єктів промислової власності потребують критичного аналізу, оскільки чинне адміністративне законодавство не відображає всі об’єкти інтелектуальної власності, включені до ст. 51-2 Кодексу України про адміністративні правопорушення [Кодекс, 2017 ].

На сьогодні національне законодавство у сфері промислової власності містить у собі як положення, закріплені у конвенціях з охорони об’єктів промислової власності, так і положення, закріплені у директивах СС. Водночас складність об'єктів права інтелектуальної власності породжує низку проблемних питань у правозастосовній та практичній діяльності, не останнє місце серед яких посідає проблема визначення законодавчого акта, який необхідно застосовувати в регулюванні відносин, пов'язаних із охороною об’єктів промислової власності.

У правовій системі проявляється багатогранність її структури, що пов’язано, зокрема, із застосуванням певних методів і принципів правового регулювання. Саме тому $є$ необхідним обговорення проблеми забезпечення балансу приватних та публічних інтересів як одного з основних завдань права на сучасному етапі. Для сфери інтелектуальної власності це, безперечно, є актуальним, оскільки так чи інакше сфера творчої діяльності характеризується перетинанням приватних та публічних інтересів. 
У цільному праві проявляються засади як приватного, так і публічного права. Якщо виходити з того, що приватне та публічне право утворюють єдину загальну систему права, то з огляду на їх сутність можна визначити їхнє значення для регулювання тих чи інших відносин за участі приватних осіб, держави, державних органів тощо. I залежно від того, яка група відносин аналізується, слід робити висновок щодо превалювання приватних або публічних елементів в їх регулюванні. Тобто відносини, залежно від їх конкретного змісту, підлягають регулюванню на засадах приватного або публічного права [Шляхи, 2009; 5-6 ].

Законодавство в сфері промислової власності має свої характерні засоби і інструменти регулювання, які виявляються у визначенні об'єктів промислової власності, відповідності кожного конкретного об'єкта нормативно закріпленим критеріям, статусі суб'єктів, формуванні правовідносин, способах визначення їх змісту. У той же час в системі охорони прав на об'єкти права промислової власності значну частину займають норми адміністративного права. Перш за все, це стосується норм, які регулюють повноваження державних органів на видачу охоронних документів. Вони використовують адміністративні методи:

1. Нормативний порядок отримання правової охорони;

2. Визначення категорій віднесення до об'єктів промислової власності юридично значимих утворень.

Слід зазначити, що норми, які визначають існування промислової власності, підлягають кодифікації за предметною ознакою і поділяються на види [Галянтич, 2003: 122123]:

1. Адміністративні і цивільні (за методом правового регулювання);

2. Регулятивні і охоронні (за підставами виникнення);

3. Абсолютні і відносні (за колом зобов'язаних осіб).

Із завданням охорони та захисту прав на об'єкти промислової власності тісно пов'язані норми спеціального законодавства. Це завдання конкретизоване у низці статей спеціального законодавства. П. п. 1 і 2 ст. 20 Закону України «Про охорону прав на знаки для товарів і послуг» визначають, що порушенням прав власника свідоцтва $є$ будь-яке посягання на права власника свідоцтва, передбачені ст. 16 цього Закону, в тому числі вчинення без згоди власника свідоцтва дій, що потребують його згоди, та готування до вчинення таких дій, що тягне за собою відповідальність згідно з чинним законодавством України [Закон України, 2004].

Порушенням прав власника свідоцтва вважається також використання без його згоди в доменних іменах знаків та позначень, вказаних у п.5 ст. 16 цього Закону [Закон України, 2004].

Охорона всіх форм власності розглядається Кодексом України про адміністративні правопорушення як одне з основних завдань законодавства про адміністративні правопорушення, що узгоджується з нормами Конституції України, згідно з якими держава забезпечує захист прав усіх суб'єктів права власності і господарювання, соціальну спрямованість економіки. Усі суб'єкти права власності рівні перед законом (ч. 4 ст. 13). Громадянам гарантується свобода літературної, художньої, наукової і технічної творчості, захист інтелектуальної власності, їхніх авторських прав, моральних і матеріальних інтересів, що виникають у зв' язку з різними видами інтелектуальної діяльності. Кожний громадянин має право на результати своєї інтелектуальної, творчої діяльності; ніхто не 
може використовувати або поширювати їх без його згоди, за винятками, встановленими законом (ст. 54) [Кодекс, 2017].

Сьогодні юридичний аспект адміністративно-правового регулювання, на думку Олени Чомахашвілі, залишається без структурного, логічного аналізу як на доктринальному, так і на нормативному рівні. Складність адміністративно-правового регулювання у зазначеній сфері полягає в тому, що існує значна кількість нормативно-правових актів, які містять норми, що стосуються різних галузей законодавства, превалюють у більшості своїй підзаконні акти, що ускладнює систематизацію внаслідок їх великої кількості, відсутня визначена правова термінологія [Чомахашвілі, 2010: 31]. Це можна прослідкувати на прикладі одного з об'єктів промислової власності — промислового зразка.

Тетяна Васильківська та Валерій Кращенко зазначають, що проблемність правової охорони прав на промислові зразки є настільки гострою, що навіть при проведенні формальної експертизи промислових зразків з'ясовано, що при проведенні 34 експертиз промислових зразків, здійснених експертами Українського інституту промислової власності, експерти припустилися низки помилок, які у свій час стали глибинними причинами спорів між сторонами судових процесів. Зокрема, йдеться про таке. За результатами експертизи надана правова охорона 6\% об'єктів, які не належать до тих, яким надається така охорона відповідно до Закону України «Про охорону прав на промислові зразки». У 67\% випадків виявлена невідповідність сукупності суттєвих ознак в описах промислових зразків їх опублікованим зображенням. На стадії формальної експертизи експерти, які ії проводили, у 9\% досліджень не змогли відрізнити технічний опис виробу від ознак, які характеризують промислові зразки як об'єкт творчої діяльності людини в галузі художнього конструювання. Виявлено, що у $3 \%$ досліджених промислових зразків існує їх невідповідність вимозі єдності [Васильківська \& Кращенко, 2008: 22-23].

У питаннях охорони прав на об'єкти промислової власності норми спеціального законодавства, що регулюють правовідносини в цій сфері, безпосередньо не пов'язані 3 адміністративною відповідальністю. Основним джерелом норм, які встановлюють адміністративну відповідальність, є Кодекс України про адміністративні правопорушення та Митний кодекс України. Вказані кодекси містять норми, якими встановлюється адміністративна відповідальність за порушення прав на об'єкти промислової власності, і становлять собою законодавство про адміністративні правопорушення.

Склади адміністративних правопорушень, що посягають на об'єкти промислової власності, містяться в ст. 51-2 Кодексу України про адміністративні правопорушення [Кодекс, 2017]. Аналіз норм цієї статті свідчить, що законодавець до незаконного використання об'єкта права інтелектуальної власності включає: літературний чи художній твір, їх виконання, фонограми, передачі організації мовлення, комп’ютерні програми, бази даних, наукові відкриття, винаходи, корисні моделі, промислові зразки, знаки для товарів і послуг, топографії інтегральної мікросхеми, раціоналізаторські пропозиції, сорти рослин тощо, якщо здійснюється привласнення авторства на такий об'єкт або інше умисне порушення прав на об'єкт права інтелектуальної власності, що охороняється законом [Кодекс, 2017].

\section{Висновки}

Здійснене дослідження свідчить про відсутність в нормах адміністративного закону такого об’єкта промислової власності, як географічне зазначення. Для правильної 
кваліфікації вчиненого правопорушення обов'язковим $є$ встановлення та правильне визначення об'єкта адміністративного правопорушення. Точне встановлення об'єкта адміністративного правопорушення повинне бути обумовлене існуючою системою охорони зазначеного інституту права інтелектуальної власності Цивільним (ст. ст. 501-504), Господарським (ст. ст. 160-161) та Кримінальним (ст. 229) кодексами України. Наявність такої системи правової охорони визначає необхідність адміністративно-правової охорони географічного зазначення шляхом включення цього об'єкта до ст. 51-2 Кодексу України про адміністративні правопорушення.

Точне встановлення об'єкта правової охорони повинне бути зумовлене й існуючою системою охорони права на географічне зазначення походження товару законодавством України.

3 метою удосконалення правової охорони прав на географічне зазначення, пропонуємо внести зміни до ст. 51-2 Кодексу України про адміністративні правопорушення шляхом включення цього об' єкта до норм статті.

3 метою удосконалення адміністративного законодавства пропонується ст. 51-2 Кодексу України про адміністративні правопорушення викласти у такій редакції:

Ст. 51-2.«Порушення прав на об'єкт права інтелектуальної власності».

Незаконне використання об’єкта права інтелектуальної власності (літературного чи художнього твору, їх виконання, фонограми, передачі організації мовлення, комп'ютерної програми, бази даних, наукового відкриття, винаходу, корисної моделі, промислового зразка, знака для товарів і послуг, топографії інтегральної мікросхеми, географічного зазначення, раціоналізаторської пропозиції, сорту рослин тощо), привласнення авторства на такий об’єкт або інше умисне порушення прав на об’єкт права інтелектуальної власності, що охороняється законом, — тягне за собою накладення штрафу від десяти до двохсот неоподатковуваних мінімумів доходів громадян з конфіскацією незаконно виготовленої продукції та обладнання і матеріалів, які призначені для іiї виготовлення.

\section{Література}

Васильківська, Тетяна; Кращенко, Валерій. Судова експертиза запатентованих промислових зразків у цифрах і фактах. Теорія і практика інтелектуальної власності. 6, 2008: 13-25.

Галянтич, М. Співвідношення правових категорій «охорона» та «захист» промислової власності. Актуальні проблеми держави і права. 19, 2003: 121-134.

Закон України «Про охорону прав на знаки для товарів і послуг». Відомості Верховної Ради України (ВВР), 7, 1994. ст. 36.

Кодекс України про адміністративні правопорушення (статті 1 -212-21). 2017. https://zakon.rada.gov.ua/laws/show/80731-10

Шляхи удосконалення правової охорони та захисту об'єктів промислової власності в Україні: аналіз, пропозиції. За ред. О. Орлюк. Київ: ТОВ «Лазуріт-Поліграф», 2009.

Чомахашвілі, Олена. Зміст адміністративно-правового регулювання у сфері охорони прав на промислові зразки. Теорія і практика інтелектуальної власності. 6, 2010: 27-32.

NASA 2018. Strategic Plan. 2017. https://www.nasa.gov/sites/default/files/atoms/files/ nasa_2018_strategic_plan.pdf 


\section{[ㅁ] References}

Vasylkivska, Tetiana; Krashchenko, Valerii. Sudova ekspertyza zapatentovanykh promyslovykh zrazkiv u tsyfrakh i faktakh. Teoriia i praktyka intelektualnoi vlasnosti. 6, 2008: 13-25.

Haliantych, M. Spivvidnoshennia pravovykh katehorii «okhorona» ta «zakhyst» promyslovoi vlasnosti. Aktualni problemy derzhavy i prava. 19, 2003: 121-134.

Zakon Ukrainy «Pro okhoronu prav na znaky dlia tovariv i posluh». Vidomosti Verkhovnoi Rady Ukrainy (VVR), 7, 1994. st. 36.

Kodeks Ukrainy pro administratyvni pravoporushennia (statti 1 - 212-21). 2017. https:// zakon.rada.gov.ua/laws/show/80731-10

Shliakhy udoskonalennia pravovoi okhorony ta zakhystu obiektiv promyslovoi vlasnosti $v$ Ukraini: analiz, propozytsii. Za red. O. Orliuk. Kyiv: TOV «Lazurit-Polihraf», 2009.

Chomakhashvili, Olena. Zmist administratyvno-pravovoho rehuliuvannia u sferi okhorony prav na promyslovi zrazky. Teoriia i praktyka intelektualnoi vlasnosti. 6, 2010: 27-32.

NASA 2018. Strategic Plan. 2017. https://www.nasa.gov/sites/default/files/atoms/files/ nasa_2018_strategic_plan.pdf 